\title{
Kesiapan Generasi Milenial Sebagai Role Model di Era New Normal
}

\author{
Riesty Amaylia Safitri \\ Universitas Sebelas Maret \\ milamiloping@student.uns.ac.id
}

\section{Article History}

received $1 / 9 / 2021$

\author{
revised 1/10/2021 accepted 1/11/2021
}

\begin{abstract}
In 2020, the year the demographic bonus begins, the millennial generation is in the age range of 20 years to 40 years. This age is a productive age which is predicted to be the backbone of Indonesia's change. However, before achieving the optimization of the demographic bonus which is considered to have a positive impact, Indonesia was first hit by the Covid-19 outbreak with a very fast transmission. Not wanting to linger in uncertainty when the pandemic will end, the Government finally decided to live side by side with Cov19, one of which was by issuing a New Normal policy with the aim of keeping people productive and safe from Covid-19 during the pandemic. Therefore, the community needs a role model that can be used as an ideal role model and example. The millennial generation with all the characteristics and skills they have in this phase is seen as being able to become a role model in facing rapid changes and new orders in society. The approach used is a qualitative approach using literature study methods from books, journals and other sources relevant to the title. The result of this paper is that the productive age of the millennial generation has been in the take off phase, meaning that it can be used as a role model by the community.
\end{abstract}

Keywords: millenial generation, role model, new normal

\section{Abstrak}

Pada tahun 2020, tahun dimulainya bonus demografi, generasi milenial berada pada rentang usia 20 tahun hingga 40 tahun. Usia tersebut adalah usia produktif yang digadang-gadang akan menjadi tulang punggung perubahan Indonesia. Namun, sebelum mencapai optimalisasi bonus demografi yang dianggap dapat memberikan dampak positif, Indonesia lebih dulu dilanda wabah Covid19 dengan peenularan yang sangat cepat. Tidak mau berlama-lama terbelenggu dalam ketidak pastian kapan berakhirnya pandemi akhirnya Pemerintah memutuskan untuk hidup berdampingan dengan Cov19, salah satunya dengan mengeluarkan kebijakan New Normal dengan tujuan agar masyarakat tetap produktif dan aman dari Covid-19 di masa pandemi. Oleh karena itu masyarakat membutuhkan role model yang dapat dijadikan panutan dan contoh yang ideal. Generasi millennial dengan segala karakteristik dan skill yang dimilikinya dalam fase ini dipandang sudah mampu menjadi role model dalam menghadapi perubahan yang sangat cepat dan tatanan baru di tengah masyarakat. Pendekatan yang digunakan adalah pendekatan kualitatif dengan menggunakan metode studi literatur dari buku, jurnal dan sumber lainnya yang relevan dengan judul.Hasil dari penulisan ini adalah usia produktif generasi millenial sudah difase take off artinya dapat dijadikan role model oleh msyarakat.

Kata kunci: generasi milenial, role model, new normal

Social, Humanities, and Education Studies (SHEs): Conference Series https://jurnal.uns.ac.id/shes

p-ISSN 2620-9284

e-ISSN 2620-9292 


\section{PENDAHULUAN}

Penyebutan Generasi dalam Profil Generasi Milenial Indonesia (2018:13-17) dijelaskan dengan berbagai jenis. Penelitian tentang perbedaan generasi ini pertama kali dilakukan oleh Manheim (1952). Menurut Manheim generasi adalah suatu konstruksi sosial yang di dalamnya terdapat sekelompok orang yang memiliki kesamaan umur dan pengalaman historis yang sama. Individu yang menjadi bagian dari satu generasi, adalah mereka yang memiliki kesamaan tahun lahir dalam rentang waktu 20 tahun dan berada dalam dimensi sosial dan dimensi sejarah yang sama. Masih dalam yang sama menurut peneliti Kupperschmidt (2000) generasi adalah sekelompok individu yang mengidentifikasi kelompoknya berdasarkan kesamaan tahun kelahiran, umur, lokasi, dan kejadian-kejadian dalam kehidupan kelompok individu tersebut yang memiliki pengaruh signifikan dalam fase pertumbuhan mereka. Selanjutnya penyebutan generasi tersebut mengalami penggolongan-penggolongan lain salah satunya adalah menurut faktor demografi khususnya tahun kelahiran seseorang. Pengelompokan terbaru dilakukan oleh Bencsik, Csikos dan Juhez (2016) sebagaimana dikutip Putra (2016 : 8) dimana hasil penelitiannya menunjukkan adanya pengelompokan generasi, yaitu Veteran Generation (1925-1946), Baby Bom Generation (1946-1960), X Generation (1960-1980), Y Generation/Generasi Millennial (1980-1995), Z Generation (1995-2010) dan Alfa Generation (2010+).

Berdasar Statistik Gender Tematik : Profil Generasi Millennial Indonesia 2018, bonus demografi pada dasarnya tidak terlepas dari generasi milenial. Menurut Kementrian Pemberdayaan Perempuan dan Perlindungan Anak dengan Badan Pusat Statistik (2018: 7), menyebutkan Rasio ketergantungan Indonesia tahun 2015 sebesar $49,20 \%$ secara tidak langsung memiliki makna bahwa persentase jumlah penduduk usia produktif mencapai sekitar $67,02 \%$ dari jumlah penduduk keseluruhan. Selanjutnya, jika persentase jumlah penduduk usia produktif ini dikaitkan dengan persentase generasi milenial tahun 2017 yang sebesar 33,75\% dari jumlah penduduk keseluruhan. Ini berarti bahwa sumbangan generasi milenial dalam membentuk struktur jumlah penduduk usia produktif tergolong cukup tinggi, karena sekitar 50,36\% dari jumlah penduduk usia produktif pada dasarnya merupakan generasi milenial. Kemudian peningkatan jumlah penduduk usia produktif terjadi lebih cepat dari perkiraan pemerintah. Pada September 2020, jumlah penduduk usia 15-64 tahun sudah mencapai 70,7\% dari total penduduk Indonesia atau sekitar 191 juta (Primus Dorimulu, 2021).

Pada tahun 2020, tahun dimulainya bonus demografi, generasi milenial berada pada rentang usia 20 tahun hingga 40 tahun. Usia tersebut adalah usia produktif yang digadang-gadang akan menjadi tulang punggung perubahan Indonesia. Namun, sebelum mencapai optimalisasi bonus demografi yang dianggap dapat memberikan dampak positif, Indonesia lebih dulu dilanda wabah Covid19 dengan penularan yang sangat cepat.

Pandemi Covid19 di Indonesia sejak awal 2020 lalu membawa banyak sekali perubahan yang tidak disangka-sangka. Hampir seluruh lapisan masyarakat dan semua sektor kehidupan terkena dampak pandemi ini. Dalam laman resmi Kementrian Kesehatan, 19 Juni 2020 menuliskan Selama 3 bulan kita hidup penuh dengan berita tentang Covid-19, di TV, radio, media sosial atau media digital, obrolan di rumah, di kantor, dan di telepon juga bicara tentang Covid-19. Berbagai respon dan reaksi ditunjukkan oleh masyarakat, ada yang sedih, cemas, takut, gemas, khawatir, marahmarah, tetapi ada juga yang tenang atau tetap percaya diri. Tidak mau berlama-lama terbelenggu dalam ketidak pastian kapan berakhirnya pandemi akhirnya Pemerintah memutuskan untuk hidup berdampingan dengan Cov19, salah satunya dengan mengeluarkan kebijakan New Normal, yang artinya adalah suatu tindakan atau perilaku yang dilakukan oleh masyarakat dan semua institusi yang ada di wilayah 
tersebut untuk melakukan pola harian atau pola kerja atau pola hidup baru yang berbeda dengan sebelumnya.

Tujuan dari New Normal adalah agar masyarakat tetap produktif dan aman dari Covid-19 di masa pandemi. "New Normal" dinarasikan menjadi "Adaptasi Kebiasaan Baru". Maksud dari Adaptasi Kebiasaan Baru adalah agar kita bisa bekerja, belajar dan beraktivitas dengan produktif di era Pandemi Covid-19. Oleh karena itu masyarakat membutuhkan role model yang dapat dijadikan panutan dan contoh yang ideal. Generasi millennial dengan segala karakteristik dan skill yang dimilikinya dalam fase ini dipandang sudah mampu menjadi role model dalam menghadapi perubahan yang sangat cepat dan tatanan baru di tengah masyarakat.

Ketua MPR, Bambang Soesatyo, bahkan pernah menyampaikan agar generasi millennial dapat menjadi pemimpin bangsa yang adil dan amanah dengan tidak lupa bernapaskan pancasila sebagai ideologi dan jatidiri bangsa. Dalam konteks kehidupan bermasyarakat, berbangsa dan bernegara hadirnya pemimpin yang adil dan amanah adalah muara pada lahirnya kepercayaan masyarakat. Dengan diperolehnya kepercayaan rakyat, kepemimpinan akan berjalan efektif dan berdampak pada optimalisasi berbagai program pembangunan. Selanjutnya, keberhasilan program pembangunan akan membawa berbagai manfaat untuk rakyat. la menjelaskan terdapat prinsip good and clean governance(pemerintahan yang baik dan bersih) untuk mewujudkan tata kelola pemerintahan yang adil dan amanah.

Berdasarkan latar belakang tersebut, penulisan artikel ini dimaksudkan untuk mengetahui karakteristik generasi millennial dan untuk mengetahui kesiapan generasi millennial sebagai role model diera new normal.

\section{KAJIAN TEORI}

Penulisan artikel ini berangkat dari keresahan penulis akan warta kepimpinan dalam perspektif millenial dengan menggunakan beberapa tulisan dan penelitian yang sudah ada sebelumnya.

Menurut Yonatan (2020) Membahas perihal kepemimpinan tidak akan pernah habis selama dunia ini masih berputar, namun kepemimpinan adalah seni untuk menyakinkan dan memberikan kepastian kepada orang lain, atau dengan kata lain kepemimpinan adalah suatu proses untuk memengaruhi orang lain. Sependapat dengan hal tersebut, Richar I. Lester menyatakan bahwa: kepemimpinan suatu konsep menajemen yang garis besarnya merupakan suatu seni memengaruhi dan mengarahkan orang lain dengan cara yang bijak, smart melalui teladan, kepatuhan, kepercayaan, hormat, dan memiliki team work yang bersemangat dalam mencapai tujuan organisasi bersama. Di generasi milennial yang merupakan kelompok dari generasi digital memiliki sebuah pengertian yang pada saat ini menjadi suatu hal yang fenomenal dan seringkali dibicarakan oleh banyak orang (Mutia, 2017). Generasi yang menselaraskan kehidupan untuk dapat diaplikatifkan dalam bentuk bertransformas dengan kehidupan sosial sebagai aspek yang penting. Terlebih media sosial menjadi sarana yang mendominasi kemajuan teknologi dalam berkomunikasi yang cepat.

Kemudian menurut Huffman: 2015 (dalam Ambarwati, Raharja 2018) Ada satu hal penting yang cukup menarik mengenai konsep kepemimpinan untuk masyarakat milenial yakni kepemimpinan itu merupakan suatu karakter dari seorang pemimpin yang mana salah satunya seseorang pemimpin harus menjadi teladan bagi orang lain atau bagi masyarakat yang dipimpinnya. Layaknya posisi seorang ibu dan ayah bagi anak dalam lingkungan keluarga, maka seorang pemimpin juga seolah menjadi orang tua bagi masyarakat yang dipimpinnya, masyarakat milenial tersebut pada akhirnya akan mencontoh apa yang dilakukan oleh pemimpin. Maka sebagai seorang pemimpin untuk era milenial, selain harus mempunyai jiwa kepemimpinan yang baik, mempunyai kapasitas dan kapabilitas dalam memimpin sehingga bisa menciptakan kondisi yang efektif, efisien dan produktif, juga seorang pemimpin milenial harus mampu mempunyai 
karakter atau atitude yang baik sehingga ia menjadi teladan bagi rakyatnya. Segala tindak tanduk pemimpin akan menjadi penilaian bagi masyarakatnya, baik itu tindakannya sebagai pemimpin suatu lembaga atau dalam hal tindakan ia sebagai masyarakat biasa termasuk dalam ranah sosialisasi dengan masyarakatnya.

Selanjutnya menurut Nanggala (2020) dalam Jurnal Peran Generasi Muda dalam Era New Normal, menyatakan, Nyatanya Generasi muda memiliki beberapa keunggulan dari generasi lainnya, keunggulan tersebut, umumnya mengarah pada sifat kreatifitas, idealisme, serta melek terhadap terknologi, sehingga kelebihan tersebut harus diberdayakan oleh generasi muda, khususnya dalam upaya mengatasi berbagai

dampak dari pandemi Covid-19 dimasyarakat. Faktanya hal tersebut merepresentasikan bahwa ideologi Pancasila masih terpatri pada generasi muda, melalui kesadarannya dalam melakukan berbagai aktivitas positif selama pandemi Covid-19, baik secara personal maupun komunitas, serta berkonsepkan langsung maupun daring (online).

Berdasar beberapa landasan teori tersebut, pendekatan yang digunakan adalah pendekatan kualitatif dengan menggunakan metode studi literatur. Studi Literatur adalah cara untuk menyelesaikan persoalan dengan menelusuri sumbersumber tulisan yang pernah dibuat sebelumnya. Dengan kata lain, istilah Studi Literatur ini juga sangat familiar dengan sebutan studi pustaka. Dalam sebuah penelitian yang akan dijalankan, tentunya seorang peneliti harus memiliki wawasan yang luas terkait objek yang akan diteliti. Sumber-sumber yang diteliti pun tidak boleh sembarangan. Sebab tidak semua hasil penelitian bisa dijadikan acuan. Beberapa yang umum dan layak digunakan adalah buku-buku karya pengarang terpercaya (lebih disarankan karya akademisi), jurnal-jurnal ilmiah terakreditasi, dan hasil-hasil penelitian mahasiswa dalam berbagai bentuk misalnya skripsi, tesis, disertasi, laporan praktikum, dan sebagainya.

\section{HASIL DAN PEMBAHASAN}

\section{Karakteristik Generasi Millennial}

Generasi Y (kelahiran 1977-1998) dikenal juga dengan nama Millenials yang disadur dari istilah pada buku Strauss dan Howe "Millenials Rising : The Next Generation". Millenials percaya bahwa pendidikan adalah kunci untuk sukses dan mereka siap untuk menjadi pembelajar seumur hidup (Mujtaba, 2010). Generasi Y memiliki tingkat harga diri dan narsisme (menganggap diri baik) lebih besar daripada generasi sebelumnya. Bursch (2014) mengatakan bahwa Generasi Y diidentifikasikan sebagai Generasi yang paling beragam (sifat, perilaku dan kultur) dan Generasi $Y$ akan sangat mewarnai keragaman di tempat kerja. Generasi $Y$ tumbuh pada dunia yang selalu terhubung selama 24 jam dan 7 hari sehingga bagi Generasi Y, informasi adalah hal yang cenderung mudah dan cepat didapatkan (Napitupulu:2018).

Masih menurut Bursch (2014) (dalam Napitupulu : 2018) menuliskan bahwa Generasi $Y$ adalah Generasi yang paling tinggi tingkat pendidikannya. Generasi $Y$ mendambakan pekerjaan dimana mereka turut ambil bagian dalam misi organisasi. Nilai pekerjaan yang berarti serta membantu orang lain adalah hal yang lebih berarti dibandingkan dengan mendapatkan uang dalam jumlah besar. Generasi Y memilih atasan yang memiliki pendekatan secara pendidikan (empiris) serta memberi perhatian terhadap tujuan pribadi dari Generasi Y. Nilai seorang Generasi Y terhadap atasannya adalah orang yang melatih mereka, bersikap positif, mampu memotivasi, berorientasi terhadap pencapaian. Kemudian karakteristik dari Generasi $Y$ di tempat pekerjaan adalah pumpun pada karir pribadi, optimis, berpihak pada keragaman, team player, cerdas teknologi, menyenangkan, kehidupan pekerjaan seimbang, mengharapkan 
pengakuan terhadap nilai pekerjaan (Acar, 2014). Generasi $Y$ selalu mencari lingkungan yang sempurna dimana mereka dapat mempelajari kemampuan dan pengalaman untuk masa depan mereka. Selain itu Generasi Y membutuhkan iklim kerja yang positif dari rekan kerja mereka (Fernandes, 2012).

Mengutip Napitupulu : 2018, menurut Olaf Swantee, CEO Everything Everywhere (EE), sebuah perusahaan telekomunikasi, mengutip ungkapan Welch di Linkedln. Swantee mengatakan ada tiga karakteristik yang dimiliki oleh para pemimpin Generasi Y di masa depan:

Kolaborasi para pengambil keputusan.

Memiliki akses ke jaringan yang luas dari kolaborator ahli adalah penting untuk mendapatkan beberapa pandangan dalam mengambil keputusan. Para pemimpin masa depan perlu berhubungan dengan orang lain, dapat bergaul dengan orang lain, dan mengekspresikan pandangan mereka dengan cara yang mudah dimengerti

Lentur dan dapat berhubungansecara pribadi.

Para pemimpin Generasi $Y$ bekerja sesuai dengan bakat mereka. Tempat kerja, praktek kerja, dan peralatan kerja akan menjadi jauh lebih pribadi dan dapat disesuaikan. Lingkungan kerja akan menjadi lebih lentur dan manusiawi. Generasi Y tumbuh dengan teknologi dan mampu berinteraksi dengan para profesional di jaringan mereka pada tingkat yang lebih pribadi dibandingkan dengan generasi sebelumnya.

Mereka dipersiapkan untuk menantang status quo.

Generasi $\mathrm{Y}$ bergairah terhadap kemajuan yang cepat, inovasi dan kewirausahaan. Kecepatan pengambilan keputusan akan menjadi penting dalam berbagai macam bisnis. Akses ke data dan insight akan menjadi seketika untuk mendukung tanggapan untuk masalah dan eksploitasi peluang dengan cepat. Generasi Y tumbuh dengan teknologi dan menyaksikan bagaimana perusahaan industri berubah dengan cepat. Mereka menyadari bahwa mereka perlu berubah dengan cepat dan memiliki strategi jika mereka ingin menang dalam persaingan. Mereka tidak menyesuaikan gaya mereka dengan yang generasi Baby Boomers sebelumnya dalam rangka untuk menyesuaikan diri dengan kelompok manajemen dimana mereka bekerja.

Selanjutnya Brander, Patterson, \& Chan, 2012 (dalam Amiroh, 2018) karakter yang harus dimiliki pemimpin milenal adalah:

Mampu menjadi teladan yang baik

seorang pemimpin untuk era milenial, selain harus mempunyai jiwa kepemimpinan yang baik, mempunyai kapasitas dan kapabilitas dalam memimpin sehingga bisa menciptakan kondisi yang efektif, efisien dan produktif, juga seorang pemimpin milenial harus mampu mempunyai karakter atau atitude yang baik sehingga ia menjadi teladan bagi rakyatnya. Segala tindak tanduk pemimpin akan menjadi penilaian bagi masyarakatnya, baik itu tindakannya sebagai pemimpin suatu lembaga atau dalam hal tindakan ia sebagai masyarakat biasa termasuk dalam ranah sosialisasi dengan masyarakatnya (Huffman, 2015).

Ketika dalam suatu negara sudah banyak terjadi hal hal tindakan pemerintah yang kurang baik, seperti korupsi, penyimpangan sosial dan lain sebagainya. Hasilnya selain 
masyarakat yang tidak mendapatkan contoh yang baik dari pemimpinnya, juga mucul ketidak percayaan dari rakyat kepada pemerintah yang tentunya hal ini sangat merugikan dalam proses pemerintahan di negara tersebut. Maka dari itu sebagai seorang pemimpin, sudah seharusnya kita membangun sikap yang baik agar menjadi teladan bagi siapa nanti yang kita pimpin, sehingga terbangun masyarakat yang baik dan menciptakan efektifitas dalam pembangunan karena diharapkan adanya antusias yang besar dari rakyat milenial terhadap pemimpinya(Wu, Tang, Dong, \& Liu, 2015).

\section{Memiliki rasa tanggung jawab}

Pemimpin yang ideal salah satunya pemimpin yang bertanggung jawab. Bertanggung jawab berarti berani untuk menanggung efek dari segala keputusan yang timbul akibat tindakan yang telah dilaksanakan. Selain cerdas dan berinisatif, seorang pemimpin yang ideal tentunya perlu memiliki sifat bertanggung jawab. Pengambilan keputusan terhadap cara kerja dan pelaksanaan misi suatu kelompok tentunya diputuskan dengan tidak tergesa-gesa(Setyaningrum, 2017).

Maka, pemimpin yang bertanggung jawab adalah pemimpin yang tetap teguh dan mampu berpikir taktis untuk menerima segala resiko yang timbul dari keputusan yang diambil. Pemimpin selalu berjiwa besar, menerima kritik dan selalu mengambil tanggung jawab atas semua keputusan yang ia ambil. Serta tidak pernah mencari kambing hitam atau menyalahkan orang di sekitarnya (Chullen, Dunford, Angermeier, Boss, \& Boss, 2010).

\section{Berani mengambil dan bersedia menerima resiko}

Konsekuensi apapun yang akan kita dapatkan dari sebuah keputusan, haruslah kita sikapi dengan positif karena hal itu dapat menjadi pemacu kehidupan kita dalam membangun integritas diri dan menyikapi suatu masalah, hal inilah yang dialami oleh para pemimpin bangsa kita yaitu keterlambatan dalam menyikapi masalah sehingga menyebabkan lambatnya negara kita dalam berkembang dikarenakan lambatnya sang pemimpin dalam menyikapi sebuah masalah dan ketidak beraniannya pemimpin kita dalam mengambil resiko karena hal yang terdapat dalam otak para petinggi negara kita hanyalah uang sehingga mengorbankan kedewasaan negara kita sendiri dan berakibatkan pada perekonomian negara(Choi, 2014).

Mempunyai sense of belonging dari para bawahan dan sense of participation

Dalam sebuah perkumpulan tidak akan terlepas dari sosok seorang leaders, mulai dari perkumpulan sederhana sampai oranganisasi besar peran pemimpin sangat vital. Maju mundurnya sebah organisasi sangat tergantung dari seorang leaders. Pemimpin adalah sosok yang sangat berperan dalam menahkodai sebuah organisasi. Tetapi sehebat apapun kepemimpinan seseorang tanpa didukung dengan managemen tim yang bagus itupun akan percuma, jadi kesolidan sebuah organisasi juga sangat penting agar oranganisasi itu bisa terus melaju sesuai dengan cita-citanya. pemimpin mempunyai tanggung jawab memastikan setiap anggotanya bekerja dengan baik, pemimpin juga harus memastikan program-program kerja berjalan. selain itu seorang pemimpin juga harus mempunyai kepekaan sosial yang tinggi, pemimpin tidak bisa bertindak semena-mena menyuruh ini itu, tanpa melihat kondisi lapangan atau anggota. Pemimpin harus tegas tetapi juga harus bijak dalam mengambil setiap keputusan. pemimpin yang tidak kreatif adalah pemimpin yang gagal, karena seharusnya pemimpin harus memunculkan inovasi-inovasi dalam setiap gagasannya, memunculkan hal-hal baru dengan gagasan-gagasan yang sepektakuler, beda dengan yang lainnya. pemimpin bukan mereka yang hanya menerima mandat lalu 
menjalankan tugas kalau seperti ini bukan pemimpin tetapi PLT (Dillard, Hale, \& Segrin, 1994).

Menciptakan kerjasama yang baik di kalangan anggota

Menjadi seorang pemimpin yang baik pada generasi masyarakat milenial saat ini dan kedepan menjadi satu tantangan yang kritis. Banyak pendapat yang mengatakan bahwa kepemimpinan merupakan karakter sejak lahir. Pada zaman ketika pemimpin dilahirkan dari para raja-raja bisa dikatakan demikian karena yang mendapatkan ilmuilmu dan pengalaman kepemimpinan hanya ada di lingkungan kerajaan (Carlyle, 2008).

Pemimpin juga harus memliki sifat berani mengambil keputusan yang terbaik untuk kepentingan rakyat atau golongannya. Yang terpenting dari semua karakter tersebut seorang pemimpin harus memiliki sifat jujur, karena ketidakjujuran bisa merusak sendisendi dalam berbangsa dan bernegara. Ketidakjujuran adalah sebuah penyakit yang sangat sulit diobati. Sekali melakukan kebohongan akan menuntut ketidakjujuranketidakjujuran berikutnya(Kamani \& Namdari, 2012).

Sebagai bangsa yang besar dan semakin diperhitungkan di kancah internasional, Indonesia memiliki banyak tantangan yang harus diselesaikan. Membangun Indonesia berarti membangun mental rakyatnya sehingga gagasan revolusi mental pun lahir dan dicetuskan pemerintah sebagai gerakan yang masif. Untuk proses perubahan besar itu, kepemimpinan model lama tidak akan cocok lagi dan oleh karena itu harus dikoreksi atau dikembangkan. Dengan generasi muda di Indonesia yang tumbuh begitu pesat, maka gaya kepemimpinan yang muncul pun harus menyesuaikan ritme dan polanya. Generasi milenial yang saat ini memengaruhi banyak hal juga harus dipimpin dengan gaya kepemimpinan milenial (E. G. Lambert, Hogan, Dial, Altheimer, \& BartonBellessa, 2012).

\section{Kesiapan Generasi Millennial sebagai Role Model di Era New Normal}

Melihat faktor demografi yang telah disebutkan sebelumnya, Generasi Y atau Generasi Millennial adalah sekumpulan orang yang telah memasuki usia produktif dilihat dari segi pendidikan, komunikasi, ekonomi, sosial dan budaya. Sebagai generasi yang memiliki "kematangan" fisik dan mental tersebut generasi $Y$ berada dalam posisi take off atau sudah siap untuk menjadi role model masyarakat di era new normal.

Kesiapan generasi millennial ini ditandai dengan Kreatifas, kesadaran serta tanggung jawab menjadi kunci bagi generasi muda untuk melaksanakan keterlibatannya dalam menyukseskan era new normal tersebut. Tentu terdapat berbagai strategi serta upaya yang bisa diimplementasikan oleh generasi muda, baik bersifat kelompok atau komunitas, maupun bersifat individu. Penting dalam mengamalkan pengabdian generasi muda tersebut, minimalnya sebagai kekuatan moral masyarakat serta menjadi penyambung lidah rakyat. Terlepas dari besar atau kecilnya implikasi atas peran atau keterlibatan generasi muda tersebut, yang penting mereka telah memiliki semangat moralitas untuk berkorban demi kepentingan umum (Nanggala, 2020)

Dampak dari pandemi Covid-19 mempengaruhi setiap lini kehidupan masyarakat, kemudian memaksa setiap orang untuk mampu bersiap dan bersikap. Artinya masyarakat harus siap menghadapi perubahan yang tiba-tiba dan menentukan sikapnya untuk tetap menjalankan peran dan fungsinya. Pandemi Covid-19 memberikan pelajaran berharga bagi bangsa Indonesia, selain perlu mempersiapan 
ketahanan pada bidang kesehatan yang mumpuni, juga perlu memperbaiki kualitas sarana dan prasarana yang berkaitan dengan teknologi informasi dan komunikasi di Indonesia. Tidak bisa dimungkiri eksistensi dari teknologi informasi dan komunikasi menjadi sangat penting, karena mewabahnya virus tersebut. Faktanya begitu banyak aktivitas rutin masyarakat Indonesia yang dilakukan secara daring (online), guna memutus rantai penyebaran pandemi Covid-19. Sehingga tidak bisa kita bayangkan, bagaimana aktivitas umat manusia saat mewabahnya Covid-19 yang tanpa diiringi oleh keberadaaan teknologi yang maju, tentu akan ditemukan berbagai hambatan, maka idealnya keberadaaan teknologi informasi dan komunikasi di Indonesia saat ini, perlu dioptimalkan oleh generasi muda dalam upaya pengabdian dan kemanusiaan.

Sebagai penutup menurut Kurnia Fitria dalam laman resmi itjen.kemenkeu.go.id, Dosen Fakultas Psikologi Universitas Katolik Indonesia, Puji Tania Ronauli mengatakan "Mengikutsertakan milenial dalam hubungan kerja memang memiliki tantangan sendiri. Namun, potensi dan karakteristik milenial dapat dioptimalkan untuk mendukung pencapaian tujuan dan potensi maksimal suatu organisasi. Kekuatan milenial yang dapat organisasi maksimalkan yaitu, work-life balance, antusias dan penuh semangat dalam membawa kebaruan, passionate, tech savvy, dan collaborative. Dengan begitu, organisasi akan mampu membuat mereka bekerja secara efektif dan lebih adaptif dibanding generasi sebelumnya". Sehingga generasi millenial dalam usia produktif tersebut dapat dikatakan siap untuk menjadi role model di era new normal.

\section{SIMPULAN}

Generasi $Y$ atau Generasi Millennial adalah sekumpulan orang yang telah memasuki usia produktif dilihat dari segi pendidikan, komunikasi, ekonomi, sosial dan budaya. Sebagai generasi yang memiliki "kematangan" fisik dan mental tersebut generasi $Y$ berada dalam posisi take off atau sudah siap untuk menjadi role model masyarakat di era new normal. Potensi dan karakteristik milenial dapat dioptimalkan untuk mendukung pencapaian tujuan dan potensi maksimal suatu organisasi. Kekuatan milenial yang dapat organisasi maksimalkan yaitu, work-life balance, antusias dan penuh semangat dalam membawa kebaruan, passionate, tech savvy, dan collaborative. Dengan begitu, organisasi akan mampu membuat mereka bekerja secara efektif dan lebih adaptif dibanding generasi sebelumnya.

\section{DAFTAR PUSTAKA}

Ambarwati, Amiroh. Raharjo, Susilo Teguh. (2018)." Prinsip Kepemimpinan Character of A Leader pada Era Generasi Milenial". Philanthropy Journal of Psychology, 2 (2), 114-127.

Kementrian Pemberdayaan Perempuan dan Perlindungan Anak dengan Badan Pusat Satistik. (2018). Profil Generasi Milenial Indonesia. Jakarta. Kementrian Pemberdayaan Perempuan dan Perlindungan Anak.

Kurnia Fitri Anidya. (2020). Menyelami Karakteristik Milenial dalam Dunia Kerja. Diakses pada 25 September 2021. Dari http://www.itjen.kemenkeu.go.id

Nanggala, Agil. (2020)." Peran Generasi Muda Dalam Era New Normal”.Jurnal Widya Wacana:Jurnal IImiah,Vol.15.

Napitupulu, Young Dame R. (2018)."Gaya Kepemimpinan Generasi Y Di Dunia Kerja". Journal Of Business \& Applied Management, 11 (1), 81-115.

Primus Dorimulu. (2021). Indonesia Sedang Menikmati Bonus Demografi. Diakses pada $27 \quad$ September $2021 . \quad$ Dari https://www.beritasatu.com/ekonomi/740489/indonesia-sedang-menikmatibonus-demografi 
Putu Indah Savitri.(2021). Ketua MPR dorong generasi milenial jadi pemimpin bangsa yang adil. Diakses pada 26 September 2021. Dari https://www.antaranews.com/berita/2362138/ketua-mpr-dorong-generasimilenial-jadi-pemimpin-bangsa-yang-adil

Suhadi. Arifianto, Yonatan Alex. (2020)."Pemimpin Kristen sebagai Agen Perubahan di Era Milenial".EDULEAD: Journal of Christian Education and Leadership,Vol. 1 Edisi 2, 129-147.

Theresia Irawati. (2020). Menuju Adaptasi Kebiasaan Baru. Diakses pada 26 September 2021. Dari https://promkes.kemkes.go.id/menuju-adaptasikebiasaan-baru 